This article is licensed under the Creative Commons Attribution-NonCommercial 4.0 International License (CC BY-NC) (http://www.karger.com/Services/OpenAccessLicense). Usage and distribution for commercial purposes requires written permission.

\title{
Certolizumab Pegol-Induced Folliculitis-Like Lichenoid Sarcoidosis in a Patient with Rheumatoid Arthritis
}

\author{
Hiroyuki Sakai Wakana Nomura Motoshi Sugawara \\ Department of Dermatology, Asahikawa City Hospital, Asahikawa, Japan
}

\section{Keywords}

Anti-TNF- $\alpha \cdot$ Lichenoid sarcoidosis · Paradoxical reaction $\cdot$ Certolizumab pegol $\cdot$ Rheumatoid arthritis

\begin{abstract}
Anti-tumor necrosis factor $\alpha$ (TNF- $\alpha$ ) biologic agents are used for treating refractory sarcoidosis. However, sarcoidosis-like epithelioid cell granulomas may develop during anti-TNF$\alpha$ treatment. A 63-year-old man suffering from rheumatoid arthritis was treated with oral methotrexate and methylprednisolone for 4 years. He subsequently started biweekly subcutaneous injections of certolizumab pegol. Three months later, light red follicular papules developed on his chest and they spread over the trunk and bilateral upper arms. Histopathology of a lesion showed a sharply demarcated noncaseating epithelioid cell granuloma with multi-nucleated giant cells in the upper perifollicular area. The follicular papules subsided following discontinuation of certolizumab pegol. Folliculitis-like lichenoid sarcoidosis should be included among the adverse cutaneous reactions of anti-TNF- $\alpha$ treatment.
\end{abstract}

(C) 2017 The Author(s)

Published by S. Karger AG, Basel 


\section{Introduction}

Anti-tumor necrosis factor $\alpha$ (TNF- $\alpha$ ) therapy is effective for several immune-mediated inflammatory diseases, such as rheumatoid arthritis, inflammatory bowel diseases, psoriasis, and sarcoidosis. However, anti-TNF- $\alpha$ agents may also paradoxically induce or exacerbate these inflammatory diseases. Herein, we present a case of paradoxical lichenoid sarcoidosis in a patient with rheumatoid arthritis who was treated with certolizumab pegol (CZP).

\section{Case Report}

A 63-year-old man had been suffering from rheumatoid arthritis for 4 years. He received oral methotrexate and methylprednisolone without satisfactory therapeutic response. Biweekly subcutaneous injection of CZP was added in September 2013. Three months later, he visited our clinic due to pruritic reddish eruptions on his chest. A physical examination revealed light red follicular papules that were approximately $2 \mathrm{~mm}$ in size on his chest. Topical and oral antibiotic therapies were not effective, and the skin lesions gradually spread over the trunk and bilateral upper arms (Fig. 1a, b). A skin biopsy of a papule disclosed a sharply demarcated non-caseating epithelioid cell granuloma with multi-nucleated giant cells in the upper perifollicular area. Considerable mononuclear lymphoid cells had infiltrated around the granuloma (Fig. 2). Neither Ziehl-Neelsen staining nor auramine staining identified any acid-fast bacilli. A blood test, chest roentgenographic examination, and computed tomography did not reveal any remarkable change. An ophthalmological examination did not reveal any signs of ocular sarcoidosis or tuberculosis (TB). The patient's serum angiotensinconverting enzyme level was normal. The tuberculin skin test and interferon-gamma release test (QuantiFERON ${ }^{\circledR}$ TB-Gold) results were marginally positive $(10 \times 10 \mathrm{~mm}$ and $0.10 \mathrm{IU} /$ $\mathrm{mL}$, respectively). These findings suggested the diagnosis of lichen scrofulosorum. We discontinued CZP and started anti-TB therapy. The follicular papules began to subside. However, at 8 weeks following the initiation of anti-TB therapy, exudative erythema developed with histopathological findings of epidermal spongiosis and massive dermal eosinophilic infiltration. A drug-induced lymphocyte stimulation test for rifampicin was positive and the anti-TB therapy was discontinued. During the course of these events, the patient's rheumatoid arthritis worsened with marked arthralgia, which urged us to re-initiate the CZP therapy. Several follicular papules reappeared again, but they improved with topical glucocorticoid therapy. Eight weeks after starting the second CZP treatment, the patient developed arrhythmia and CZP was discontinued. The follicular papules gradually subsided and did not develop again. We finally diagnosed the skin lesions as lichenoid sarcoidosis.

\section{Discussion}

The patient's follicular papules were initially suspected to be superficial bacterial folliculitis. However, histopathology of the lesion disclosed a non-caseating epithelioid cell granuloma in the upper dermal perifollicular area, suggesting the diagnosis of lichen scrofulosorum. This was excluded because: (1) the patient did not develop TB during the oral 
methotrexate and methylprednisolone therapy, suggesting that he did not have latent TB; (2) TB bacilli were never detected in the skin lesions; (3) no obvious systemic TB developed after the re-initiation of CZP therapy; (4) after cessation of the CZP therapy, the follicular papules subsided without anti-TB drugs; and (5) the follicular papules responded to topical glucocorticoid treatment. These findings together with the histopathology led to the diagnosis of CZP-induced lichenoid sarcoidosis.

Sarcoidosis is a multi-organ chronic inflammatory disease characterized by noncaseating epithelioid cell granulomas. TNF- $\alpha$ is among the key cytokines of granuloma formation, and anti-TNF- $\alpha$ treatment has been shown to be effective for refractory sarcoidosis $[1,2]$. More than 50 cases of anti-TNF- $\alpha$ therapy-associated sarcoidosis have been reported [1]. In approximately $75 \%$ of the cases, the clinical presentation was systemic, mainly respiratory symptoms, such as dyspnea, chest pain, and cough. So far, 17 cases, including ours, of cutaneous non-caseating "sarcoidosis-like" granulomas with or without visceral involvement have been described (Table 1). The cutaneous manifestations include papules, nodules, plaques, subcutaneous masses, scar infiltration, and follicular papules (the current case). The time lapse between the initiation of anti-TNF- $\alpha$ treatment and the onset of sarcoidosis varies from 1 month to 4 years. However, in approximately half of the cases (9/17), granulomas developed within the first year of treatment.

In conclusion, we present the first case of rheumatoid arthritis with lichenoid sarcoidosis induced by the anti-TNF- $\alpha$ agent CPZ. The patient's skin lesions mimicked superficial folliculitis, which is relatively common in cases under immunosuppressive treatments. Folliculitis-like lichenoid sarcoidosis should also be considered in patients receiving anti-TNF- $\alpha$ treatment as adverse cutaneous reactions, especially when follicular papules do not respond to conventional anti-microbial treatment.

\section{Statement of Ethics}

The authors have no ethical conflicts to disclose.

\section{Disclosure Statement}

The authors declare no conflicts of interest.

\section{References}

Baughman RP, Lower EE: Treatment of sarcoidosis. Clin Rev Allergy Immunol 2015;49:79-92. Amber KT, Bloom R, Mrowietz U, Herti M: TNF- $\alpha$ : a treatment target or cause of sarcoidosis? J Eur Acad Dermatol Venereol 2015;29:2104-2111.

-3 Peno-Green L, Lluberas G, Kingsley T, Brantley S: Lung injury linked to etanercept therpy. Chest 2002;122:1858-1860.

-4 González-López MA, Blanco R, González-Vela MC, Fernández-Llaca H, Rodríguez-Valverde V: Development of sarcoidosis during etanercept therapy. Arthritis Rheum 2006;55:817-820.

5 Bachmeyer C, Blum L, Petitjean B, Kemiche F, Pertuiset E: Granulomatous tattoo reaction in a patient treated with etanercept. J Eur Acad Dermatol Venereol 2007;21:550-552. 
-6 Verschueren K, Van Essche E, Verschueren P, Taelman V, Westhovens R: Development of sarcoidosis in etanercept-treated rheumatoid arthritis patients. Clin Rheumatol 2007;26:1969-1971.

-7 Daïen CI, Monnier A, Claudepierre P, Constantin A, Eschard JP, Houvenagel E, Samimi M, Pavy S, Pertuiset E, Toussirot E, Combe B, Morel J: Sarcoid-like granulomatosis in patients with tumor necrosis factor blockers: 10 cases. Rheumatology (Oxford) 2009;48:883-886.

$>8$ Dhaille F, Viseux V, Caudron A, Dadban A, Tribout C, Boumier P, Clabaut A, Lok C: Cutaneous sarcoidosis occurring during anti-TNF-alpha treatment: report of two cases. Dermatology 2010;220:234-237.

$>9$ Takahashi H, Kaneta K, Honma M, Ishida-Yamamoto A, Ashida T, Kohgo Y, Ohsaki Y, Iizuka H: Sarcoidosis during infliximab therapy for Crohn's disease. J Dermatol 2010;37:471-474.

10 Clementine RR, Lyman J, Zakem J, Mallepalli J, Lindsey S, Quinet R: Tumor necrosis factor-alpha antagonist-induced sarcoidosis. J Clin Rheumatol 2010;16:274-279.

11 Burns AM, Green PJ, Pasternak S: Etanercept-induced cutaneous and pulmonary sarcoid-like granulomas resolving with adalimumab. J Cut Pathol 2012;39:289-293.

12 Fok KC, Ng WW, Henderson CJ, Connor SJ: Cutaneous sarcoidosis in a patient with ulcerative colitis on infliximab. J Crohns Colitis 2012;6:708-712.

-13 Lamrock E, Brown P: Development of cutaneous sarcoidosis during treatment with tumor necrosis alpha factor antagonists. Australas J Dermatol 2012;53:e87-e90.

14 Au S, Mirsaeidi M, Aronson IK, Sweiss NJ: Adalimumab induced subcutaneous nodular sarcoidosis; a rare side effect of tumor necrosis factor- $\alpha$ inhibitor. Sarcoidosis Vasc Diffuse Lung Dis 2014;31:249_ 251.
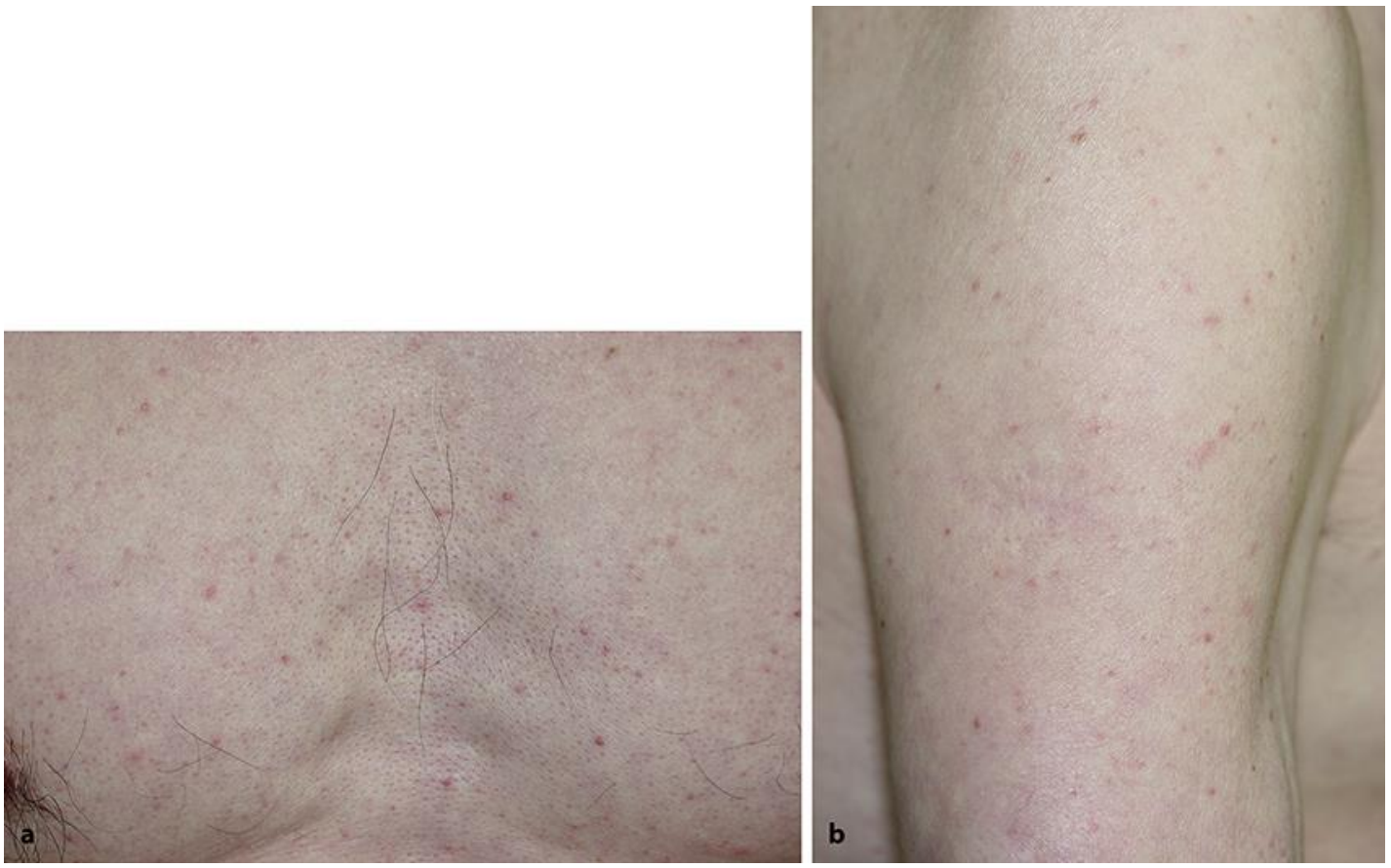

Fig. 1. Light red follicular papules of approximately $2 \mathrm{~mm}$ in size are distributed on the chest (a) and right upper arm (b). 


\section{Case Reports in Dermatology}

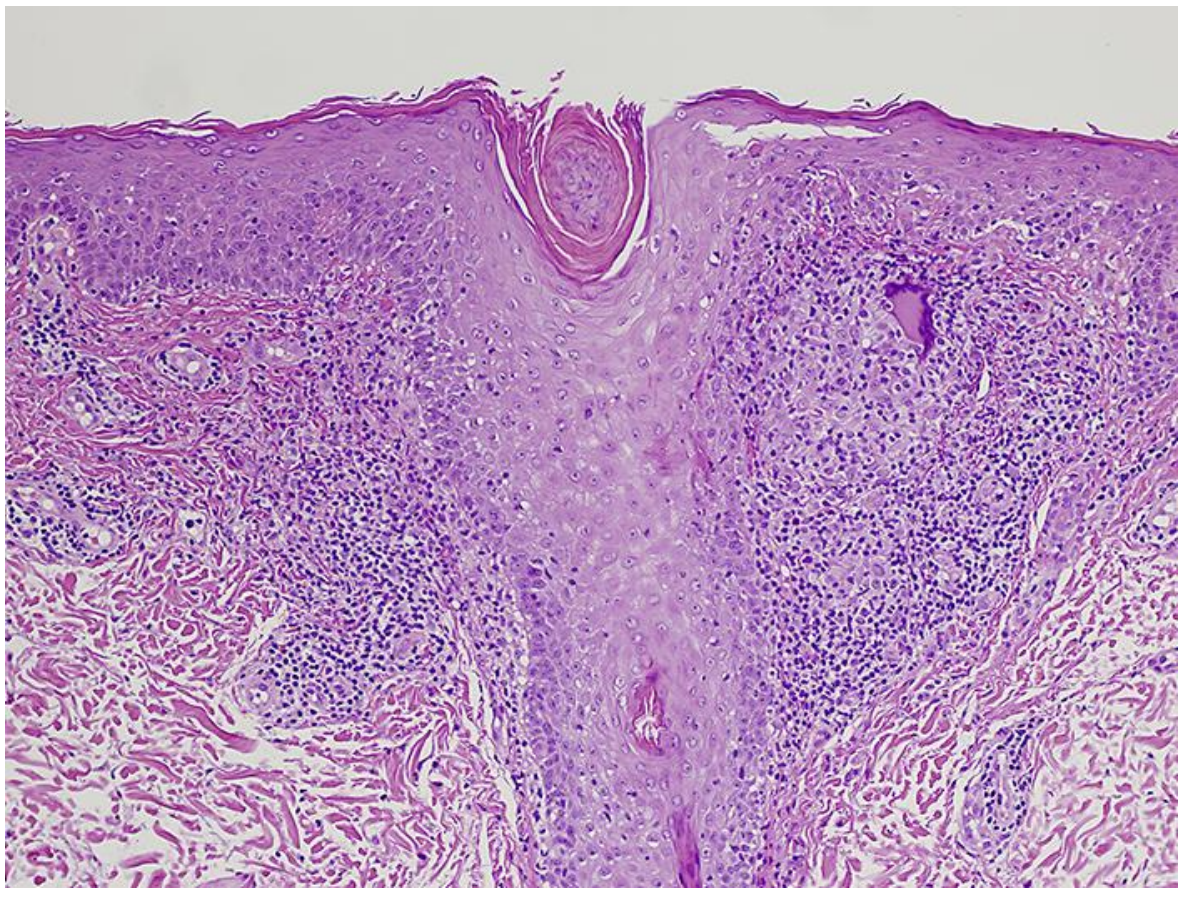

Fig. 2. A skin biopsy specimen taken from the patient's abdomen shows a sharply demarcated noncaseating epithelioid cell granuloma with multi-nucleated giant cells in the upper perifollicular area. 
Table 1. Cases of cutaneous sarcoidosis during anti-TNF- $\alpha$ treatment

\begin{tabular}{|c|c|c|c|c|c|c|}
\hline $\begin{array}{l}\text { First author } \\
\text { [Ref.] }\end{array}$ & $\begin{array}{l}\text { Anti-TNF- } \alpha \\
\text { agent }\end{array}$ & $\begin{array}{l}\text { Age, years/ } \\
\text { sex }\end{array}$ & $\begin{array}{l}\text { Underlying } \\
\text { disease }\end{array}$ & $\begin{array}{l}\text { Time interval between } \\
\text { treatment and onset }\end{array}$ & $\begin{array}{l}\text { Clinical manifestations of the } \\
\text { cutaneous granulomatous lesions }\end{array}$ & Other organ involvement \\
\hline $\begin{array}{l}\text { Peno-Green } \\
\text { [3] }\end{array}$ & ETA & $50 / \mathrm{F}$ & RA & 2 months & $\begin{array}{l}\text { Scattered nonpruritic skin lesions on the } \\
\text { plantar surfaces of both feet and at the } \\
\text { site of superficial scars on the extremities }\end{array}$ & $\begin{array}{l}\text { Diffuse reticulonodular } \\
\text { infiltrates in the mid- and lower } \\
\text { lung zones }\end{array}$ \\
\hline $\begin{array}{l}\text { González- } \\
\text { López [4] }\end{array}$ & ETA & $70 / \mathrm{M}$ & AS & 19 months & $\begin{array}{l}\text { Firm, nontender, red-brown nodular } \\
\text { lesions on the face }\end{array}$ & $\begin{array}{l}\text { Bilateral hilar and paratracheal } \\
\text { lymphadenopathy }\end{array}$ \\
\hline $\begin{array}{l}\text { Bachmeyer } \\
{[5]}\end{array}$ & ETA & $39 / \mathrm{M}$ & AS & 1 month & $\begin{array}{l}\text { Asymptomatic erythematous papules on } \\
\text { a tattoo }\end{array}$ & No \\
\hline $\begin{array}{l}\text { Verschueren } \\
\text { [6] }\end{array}$ & ETA & $46 / \mathrm{F}$ & RA & 12 months & A plaque lesion on the right forearm & $\begin{array}{l}\text { Bilateral hilar and paratracheal } \\
\text { lymphadenopathy }\end{array}$ \\
\hline \multirow[t]{4}{*}{ Daïen [7] } & ETA & $46 / \mathrm{M}$ & PsA & 2 months & Three cutaneous nodules on the face & No \\
\hline & ETA & $72 / \mathrm{F}$ & RA & 18 months & Inflammatory and painful scars & No \\
\hline & IFX & $54 / \mathrm{F}$ & AS & 14 months & Brownish nodules on arms and legs & $\begin{array}{l}\text { Basal infiltration and } \\
\text { mediastinal lymph node }\end{array}$ \\
\hline & $\mathrm{ADA}$ & $53 / \mathrm{F}$ & RA & 21 months & Nodules on lower limbs & $\begin{array}{l}\text { Mediastinal lymph nodes and } \\
\text { infiltrates }\end{array}$ \\
\hline \multirow[t]{2}{*}{$\begin{array}{l}\text { Dhaille } \\
{[8]}\end{array}$} & IFX & $47 / \mathrm{M}$ & PsA & 4 months & $\begin{array}{l}\text { Painful subcutaneous firm nodules on the } \\
\text { right temple, palms, soles, knees, sternal } \\
\text { area, and scars }\end{array}$ & No \\
\hline & ADA & $56 / \mathrm{F}$ & PJR & 1 months & $\begin{array}{l}\text { Red nodular lesions on the right forearm, } \\
\text { ankles, and legs with increased redness } \\
\text { of pre-existing scars }\end{array}$ & No \\
\hline $\begin{array}{l}\text { Takahashi } \\
{[9]}\end{array}$ & IFX & $35 / \mathrm{M}$ & $\mathrm{CD}$ & 7 months & $\begin{array}{l}\text { An infiltrated erythematous plaque on } \\
\text { the right knee }\end{array}$ & $\begin{array}{l}\text { Bilateral nodular infiltrates } \\
\text { and miliary reticulonodular } \\
\text { densities of the lung }\end{array}$ \\
\hline $\begin{array}{l}\text { Clementine } \\
{[10]}\end{array}$ & IFX & $49 / \mathrm{F}$ & RA & 60 months & $\begin{array}{l}\text { Multiple shiny violaceous erythematous } \\
\text { papules on the left lower leg }\end{array}$ & $\begin{array}{l}\text { Anterior uveitis, hilar and } \\
\text { mediastinal lymphadenopathy, } \\
\text { fibrotic lung disease }\end{array}$ \\
\hline Burns [11] & ETA & $59 / \mathrm{F}$ & $\mathrm{RA}$ & 48 months & $\begin{array}{l}\text { A subcutaneous mass measuring } 4 \times 7 \mathrm{~cm} \\
\text { on the left forearm and multiple smaller } \\
\text { nodules on the distal upper extremities, } \\
\text { knees, and buttocks }\end{array}$ & $\begin{array}{l}\text { Pretracheal, subcranial, hilar and } \\
\text { peribronchial adenopathy }\end{array}$ \\
\hline Fok [12] & IFX & $66 / F$ & UC & 23 months & $\begin{array}{l}\text { Increased prominence of previous scars } \\
\text { and several painful dermal nodules over } \\
\text { the extensor surfaces of the upper and } \\
\text { lower limbs }\end{array}$ & No \\
\hline $\begin{array}{l}\text { Lamrock } \\
{[13]}\end{array}$ & ETA & $56 / F$ & PsA & 9 months & $\begin{array}{l}\text { Erythematous nodules on the knees and } \\
\text { right elbow }\end{array}$ & No \\
\hline $\mathrm{Au}[14]$ & $\mathrm{ADA}$ & $49 / \mathrm{F}$ & Sarcoidosis & 8 months & $\begin{array}{l}\text { Multiple subcutaneous nodules on the } \\
\text { arms and legs }\end{array}$ & $\begin{array}{l}\text { Pulmonary sarcoidosis, } \\
\text { costochondritis secondary to } \\
\text { sarcoidosis }\end{array}$ \\
\hline Present case & $\mathrm{CZP}$ & $63 / \mathrm{M}$ & $\mathrm{RA}$ & 3 months & $\begin{array}{l}\text { Disseminated follicular papules on the } \\
\text { trunk and arms }\end{array}$ & No \\
\hline
\end{tabular}

AS, ankylosing spondylitis; CD, Crohn disease; PJR, polyarticular juvenile rheumatoid arthritis; PsA, psoriatic arthritis; RA, rheumatoid arthritis; UC, ulcerative colitis; ADA, adalimumab; CZP, certolizumab pegol; ETA, etanercept; IFX, infliximab. 